\title{
IMPACT OF IRRIGATION ON YIELD AND ENERGY BALANCE OF THE PRODUCTION OF OIL AND CAKE OF TWO SUNFLOWER VARIETIES
}

\author{
RODRIGO A. JORDAN ${ }^{1}$, EDER P. GOMES ${ }^{2}$, GUILHERME A. BISCARO ${ }^{3}$
}

\begin{abstract}
The energy balance for the production of sunflower oil and cake was carried out during the agricultural and industrial stage phase, where it was considered a cold extraction by hydraulic pressing, with the plant location in a rural area with a radius of $30 \mathrm{~km}$ range. Data on productivity was used in two varieties of sunflower (Helio 358 and Aguará 04) grown in different seasons (2007/2008, 2008/2009), under different irrigation levels. Data showed that irrigation resulted in an increase in productivity of both varieties, and the best response was observed for Aguará 04 variety. Moreover, the increased intensity of irrigation negatively affected the energy balance, reducing the ratio between energy produced and energy used in the production chain. The most significant inputs in the energy intake were fertilizer followed by diesel oil, when irrigation was not used for. When the irrigation technique was used, the most significant inputs, in order of representativeness, were: energy, fertilizer and equipment.
\end{abstract}

KEYWORKS: bioenergy, sunflower, irrigation, energy balance.

\section{IMPACTO DA IRRIGAÇÃO NA PRODUTIVIDADE E NO BALANÇO ENERGÉTICO DA PRODUÇÃO DE ÓLEO E TORTA DE DUAS VARIEDADES DE GIRASSOL}

RESUMO: Realizou-se o balanço energético para a produção de óleo e torta de girassol na fase agrícola e na fase de extração a frio por prensagem hidráulica, com a localização da usina em área rural, num raio de abrangência de $30 \mathrm{~km}$. Foram utilizados dados de produtividade de duas variedades de girassol (Helio 358 e Aguará 04) cultivadas em safras distintas (2007/2008, 2008/2009), submetidas a diferentes lâminas de irrigação. Os dados mostraram que a irrigação propiciou aumento de produtividade das duas variedades, sendo que a melhor resposta foi observada para a variedade Aguará 04. Por outro lado, o aumento da intensidade de irrigação afetou negativamente o balanço energético, reduzindo a relação entre energia extraída e energia utilizada na cadeia de produção. Os insumos mais representativos nas entradas de energia foram os fertilizantes, seguidos pelo óleo diesel, quando não se utilizou de irrigação. Quando utilizada a técnica de irrigação, os insumos mais significativos, em ordem de representatividade, foram: energia elétrica, fertilizantes e equipamentos.

PALAVRAS CHAVE: bioenergia, girassol, irrigação, balanço de energia.

\section{INTRODUCTION}

The growing demand for biofuels, the perspective to increase the production of vegetable oil for food and the possibility of commercialization of new products and by-products of oil industry, will contribute to the increase demand for vegetable oils. In this productive chain, the proper use of co-products (cake or bran) is a critical factor for the competitiveness of the enterprise.

In this context, the global demand for sunflower oil has been growing in an average of $1.8 \%$ per year. In 2002, in Brazil, this growth was 5\%, however, insufficient to supply domestic demand. The country imports sunflower oil mainly from Argentina (SILVA et al., 2007).

\footnotetext{
${ }^{1}$ Prof. Adjunto FCA/UFGD, área de energia. Pesquisador Colaborador FEAGRI/UNICAMP. E-mail: rodrigojordan@ufgd.edu.br. Telefone: (67) 3410-2412.

${ }^{2}$ Prof. Adjunto FCA/UFGD, área de água e solos.

${ }^{3}$ Prof. Adjunto FCA/UFGD, área de água e solos.

Recebido pelo Conselho Editorial em: 19-10-2011
}

Aprovado pelo Conselho Editorial em: 14-6-2012 
In Brazil, the biodiesel market has stimulated the market for vegetable oil. There have been anticipating of the addition of 5\%, making the B5 effective (diesel with addition of 5\% biodiesel) in 2010, which should occur in 2012. Now, oil producers are pushing for 2020 the B20 is used, increasing the addition of biodiesel in diesel fuel to $20 \%$. This shows an even more promising future for the market of vegetable oil. However, in the dispute between the food and energy, the manufacture of oil rather than biodiesel becomes strategic, because, depending on the price, you can choose between the two markets.

The sunflower has a high oil content ( $42 \%$ on average) compared to other grains, such as soybeans (average 18\%) and cottonseed (average 15\%), and it has slightly less than castor plant, which has an average of $47 \%$ oil content (YANES et al., 2008). However, it has the advantage that its cake can be exploited to animal feed, which does not occur with castor plant.

Due to high oil content, the extraction process is simpler and can be applied to cold mechanical extraction, eliminating the use of steam or solvents. Therefore, after extraction, sunflower oil may be consumed in any culinary activity (EMBRAPA, 2010).

The national average yield of sunflower is $1,500 \mathrm{~kg} \mathrm{ha}^{-1}$, resulting in a yield of $630 \mathrm{~kg} \mathrm{ha}^{-1}$ oil (EMBRAPA, 2010). However, under irrigation, sunflower grain yield may overcome the mark of 4,000kg ha ${ }^{-1}$ (KARAM et al., 2007; ANASTASI et al., 2010).

According to GAZZONI et al. (2010), during the processing of 1 ton of sunflower grain, we obtain, on average, $400 \mathrm{~kg}$ of oil, $250 \mathrm{~kg}$ of husk, and $350 \mathrm{~kg}$ of cake, with $48-50 \%$ of protein, which may be used in poultry, swine and semi or full confinement of cattle.

In terms of adaptation, the sunflower crop shows good suitability to edaphoclimatic conditions, with a good tolerance to low temperatures in the early stage of development, due to relative resistance to drought. Its yield was minimally affected by latitude and altitude, making it easy to expand its cultivation in Brazil (GOMES et al., 2010).

However, its water requirement, as well as the crop coefficients in different phenological stages, is not fully defined yet, because there is information indicating from $200 \mathrm{~mm}$ to over 900 mm per cycle (SILVA et al., 2007). Despite the drought tolerance when compared to other annual crops, the sunflower is sensitive to water availability in the soil (Tomich et al.,2003 apud MELO et al., 2008).

In this context, irrigation may help to increase crop yield. But, it is interesting to know what the economic and energy implications are. An energy evaluation in this respect is performed in this study.

\section{MATERIAL AND METHODS}

The varieties of sunflower Helio 358 and Aguará 04 were grown in the Experimental Campus of Umuarama, extension of Maringá State University, located in the northwest of the state of Paraná, in altitude equal to 430 meters, latitude $23^{\circ} 47^{\prime} 55^{\prime \prime}$ South and longitude $53^{\circ} 18^{\prime} 48^{\prime \prime}$ 'West.

For both varieties, grown in different seasons (Helio 358 - 2007/2008 harvest, Aguará 04 2008/2009), we used the same experimental design, randomized blocks, with five treatments and four replications ( 20 plots), where four treatments received different water depths, and the control was only rainwater.

Each plot had nine square meters $(3 \mathrm{~m} \times 3 \mathrm{~m})$ with $0.6 \mathrm{~m}$ between rows and $0.2 \mathrm{~m}$ between plants. Each plot consisted of five rows with 10 plants each. The two extreme lines and the last two plants of each line were considered borders. The plots were $3 \mathrm{~m}$ distant from each other. The irrigated plots contained four micro-sprinklers, one at each corner, $1.5 \mathrm{~m}$ of the soil surface.

The correction of soil, fertilizer and herbicide applications were made following recommendations found in CASTRO et al. (2006) and BRIGHENTI et al. (2006). 
Sowing of Helio 358 variety was accomplished through tillage, with prior desiccation of the area with insecticide Glyphosate (i.a) at a dose of $2 \mathrm{~kg} \mathrm{ha}^{-1}$, and soil correction in acidity level with application of $2,000 \mathrm{~kg} \mathrm{ha}^{-1}$ of dolomitic limestone (PRNT 100\%). We used fertilization with $300 \mathrm{~kg}$ $\mathrm{ha}^{-1}$ of 0-20-20 formula plus $1 \mathrm{~kg} \mathrm{ha}^{-1}$ of boron. The seeds were sown in total area. After 40 days, cover fertilization was performed using $100 \mathrm{~kg} \mathrm{ha}^{-1}$ of urea, and the application of herbicide Sethoxidim (ia) was also performed, at a dose of $0.22 \mathrm{~kg} \mathrm{ha}^{-1}$, with the addition of mineral oil at $0.5 \%$.

For Aguará 04 variety, the sowing was done in a conventional manner, with tillage involving liming, plowing and two disking. Regarding the application of fertilizers and herbicides, we used the same dosages and managements used for variety Helio 358, differing only in the dosage of limestone, which was $1,000 \mathrm{~kg} \mathrm{ha}^{-1}$.

The handling of irrigation was performed in additional form through simplified water balance, three times a week. The values of precipitation (P) and reference evapotranspiration (ETo) were determined daily using the Meteorological Station Campus, equipped with anemometer, thermohygrograph, class A tank and pluviometer. All treatments received $30 \mathrm{~mm}$ of establishment irrigation, applied twice, $15 \mathrm{~mm}$ before and $15 \mathrm{~mm}$ after sowing.

At the end of the cycle, six plants per plot were collected from the central row (third row), to determine grain yield and oil. The productivity in the form of grain yield was obtained by weighing, using scale, the resolution of $0.01 \mathrm{~g}$ and corrected by a determiner of seed moisture at $13 \%$.

For the energy balance, the agricultural phase was divided into 5 stages: pre-sowing, sowing, management, irrigation and harvesting. The pre-sowing stage comprehended activities of preparation of planting area, which corresponded to the herbicide and liming in case of the Helio 358 variety, and the activities of liming, plowing and disking in case of the Aguará 04 variety. The sowing stage corresponded solely to the operation of tillage and conventional seeder for Helio 358 and Aguará 04 varieties, respectively. The management stage comprised activities of herbicide application and fertilization with urea. The harvesting stage comprised mechanized harvesting and transport of harvested grain crop to the processing site, considering a distance of $30 \mathrm{~km}$ of transport.

In calculating the energy required to manufacture fertilizers and pesticides, we used the methodology adopted by PIMENTEL (1980) quoted by MELO et al. (2007). The energy equivalence of electricity, diesel fuel and lubricants were removed from the National Energy Balance of 2008. Table 1 shows the ratio of energy equivalents.

TABLE 1. Energy equivalences employed.

\begin{tabular}{lccc}
\hline Component & Unit & Energy $(\mathbf{M J})$ & Source \\
\hline Diesel Oil & $\mathrm{L}$ & 35.52 & EPE (2008) \\
Lubricant Oil & $\mathrm{L}$ & 37.29 & EPE (2008) \\
Grease & $\mathrm{Kg}$ & 42.38 & EPE (2008) \\
Sunflower Oil & $\mathrm{Kg}$ & 37.68 & GAZZONI et al. (2007) \\
Sunflower Cake & $\mathrm{Kg}$ & 16.75 & GAZZONI et al. (2007) \\
Sunflower Seed & $\mathrm{Kg}$ & 25.12 & Estimated \\
Nitrogen & $\mathrm{Kg}$ & 50.28 & MELO et al. (2007) \\
Phosphorus & $\mathrm{Kg}$ & 12.57 & MELO et al. (2007) \\
Potassium & $\mathrm{Kg}$ & 6.77 & MELO et al. (2007) \\
Limestone & $\mathrm{Kg}$ & 1.18 & MELO et al. (2007) \\
Boron & $\mathrm{Kg}$ & 15.35 & GAZZONI et al. (2007) \\
Herbicides & $\mathrm{Kg}$ & 418.62 & MELO et al. (2007) \\
Insecticides & $\mathrm{Kg}$ & 364.15 & MELO et al. (2007) \\
Electricity & $\mathrm{kWh}$ & 3.60 & EPE (2008) \\
Manpower & $\mathrm{H}$ & 2.16 & MELO et al. (2007) \\
\hline
\end{tabular}


The energy equivalence of sunflower seed was estimated based on energy equivalence of oil and cake, considering the mass of these present components in $1 \mathrm{~kg}$ of sunflower seeds, determined based on the amounts reported by EMBRAPA (2010): $40 \%$ of oil and 60\% of cake (bran and husks). These values were also adopted to estimate the productivity of oil and cake.

Quantification of energy related to equipment employed was performed according to MACEDÔNIO \& PICCHIONI (1985) quoted by ASSENHEIMER et al. (2009), according to service life, weight and respective energy coefficients. The energy coefficients used, in accordance with ASSENHEIMER et al. (2009), were: $69.83 \mathrm{MJ} / \mathrm{kg}$ for self-propelled equipment (motorized: tractor, harvester) and $57.20 \mathrm{MJ} / \mathrm{kg}$ for non-self-propelled equipment (plow, harrow, sprayer, etc.). For this, equations 1 and 2 were employed.

$$
\begin{aligned}
& \operatorname{Eap}(M J / h)=\frac{69,83(M J / k g) \times M(k g)}{V u(h)} \\
& \operatorname{Enp}(M J / h)=\frac{57,20(M J / k g) \times M(k g)}{V u(h)}
\end{aligned}
$$

In which,

Eap - energy of self-propelled equipment;

Enp - energy of non-self-propelled equipment;

$M$ - mass of equipment;

$V u$ - service life of equipment.

Table 2 shows the data (mass and service life) for equipment used.

\begin{tabular}{|c|c|c|}
\hline Equipment & Mass (kg) & Service Life (h) \\
\hline Tractor of $80 \mathrm{hp}$ tires & $3.000^{(2)}$ & $12.000^{(1)}$ \\
\hline Harvester of $200 \mathrm{hp}$ & $8.000^{(2)}$ & $8.000^{(1)}$ \\
\hline Seeder & $2.000^{(2)}$ & $1.200^{1}$ \\
\hline Sprayer & $840^{(2)}$ & $1.500^{(1)}$ \\
\hline Irrigation equipment $^{(3)}$ & $3.226^{(5)}$ & 40.000 \\
\hline Limestone spreader ${ }^{(4)}$ & 1.000 & 1.500 \\
\hline Plow & $1.000^{(2)}$ & $5.000^{(6)}$ \\
\hline Harrow & $1.200^{(2)}$ & $3.000^{(6)}$ \\
\hline
\end{tabular}

TABLE 2. Equipment data employed.

${ }^{1}$ Source: PACHECO (2000); ${ }^{2}$ Source: ASSENHEIMER et al. (2009); ${ }^{3}$ Source: Valmont Ind. e Com. Ltda.; ${ }^{4}$ Personal information; ${ }^{5}$ Estimated to 1 ha; ${ }^{6}$ Source: CHECHETO et al. (2010).

For the case of the irrigation system, the data used to determine the energy of the system (equipment) have been provided by the Company Valmount Ind. e Com. Ltda, which reported mass of $34.600 \mathrm{~kg}$ for a complete system of center pivot for an area of 115 hectares. We calculated, then, the radius of the area for determining the length of the pivot, and subsequently we determined the mass per linear meter by dividing the total weight by the length. We calculated the radius of the pivot for 1 ha, which was multiplied by the weight per linear meter for determining the mass per hectare provided in Table 2. We used the equation 1 because it is a self-propelled equipment.

The time spent in each agricultural operation was measured during the experiment, and it was extrapolated to values in hours per hectare. The energy consumption of an irrigation system was determined by multiplying the electric power of the water pump by operating time, which was determined based on water depth applied in each plot and the pumping capacity, it was also extrapolated for values in hectare. 
The average diesel consumption of tractor was estimated based on the methodology of the Department of Agricultural Engineering, University of Illinois - USA (KAMPHORST, 2003), which considers that a tractor operates on average with $55 \%$ of their power, using for this calculus the equation 3 . We applied the same equation for the diesel consumption of the harvester.

$$
C d(L / h)=P(k W) \times 0,243
$$

In which,

$C d$ - diesel consumption;

$P$ - engine power.

For the transport of the grains, we considered using a Ford truck F12000, having a mass of $4.320 \mathrm{~kg}$, and the load capacity of $7.480 \mathrm{~kg}$, and average consumption of $0.33 \mathrm{~km} \mathrm{~L}^{-1}$. Therewith, applying equation 1 to determine the energy of the truck and considering a service life of $400.000 \mathrm{~km}$, we estimated the energy cost for transportation, considering the distance of $30 \mathrm{~km}$ in $52.98 \mathrm{MJ} \mathrm{t}^{-1}$ of sunflower.

For the production of oil, we considered the cold extraction. The data was provided by the company Ercitec, regarding cold Micro Extractor, MUE-300 model, with a processing capacity of up to $300 \mathrm{~kg} / \mathrm{h}^{-1}$ of grain, with an extraction efficiency of $80 \%$ and total power of $35 \mathrm{hp}\left(25.76 \mathrm{~kJ} \mathrm{~s}^{-1}\right)$. To house the extractor, a shed of $100 \mathrm{~m}^{2}$ was considered. The construction indirect energy was estimated based on the amount of energy equivalence of $956.53 \mathrm{MJ} \mathrm{m}^{-2}$, extracted from ANGONESE et al. (2006), considering a service life of 30 years and a 12-hour daily use.

\section{RESULTS AND DISCUSSION}

Table 3 presents the yield data obtained for the two sunflower varieties used in the experiments, depending on the water depth applied as supplemental irrigation.

TABLE 3. Yield obtained with Helio 358 (crop 2007/2008) and Aguará 04 (crop 2008/2009) varieties under different irrigation depths.

\begin{tabular}{cccc}
\hline Treatment & $\begin{array}{c}\text { Water depth applied } \\
(\mathrm{mm})\end{array}$ & $\begin{array}{c}\text { Total water depth } \\
\text { received } \\
(\mathrm{mm})\end{array}$ & Mean yield (kg/ha) \\
\hline L0 & Helio 358 (crop 2007/2008) & \\
\hline L1 & 0.0 & $448.0^{*}$ & 2271 \\
L2 & 245.9 & 693.9 & 2441 \\
L3 & 290.2 & 738.2 & 2528 \\
L4 & 334.5 & 782.5 & 3063 \\
\hline L0 & 379.0 & 827.0 & 2488 \\
\hline L1 & Aguará 04 (crop 2008/2009) & 4642 \\
L2 & 0.0 & $454.0 *$ & 5156 \\
L3 & 99.5 & 553.5 & 5697 \\
L4 & 204.1 & 658.1 & 6237 \\
\hline
\end{tabular}

Obs: (*) only the rainfall value during the period.

The L0 treatment correspond to the control, which received no water for irrigation. During the cycle of the Helio 358 variety, rainfall totaled $448 \mathrm{~mm}$ and there was no rainfall in the establishment phase. During the cycle of the Aguará 04 variety, the total rainfall was $454 \mathrm{~mm}$, of which $194 \mathrm{~mm}$ were registered in the establishment phase (0-15 days after sowing).

The yield data, in an initial comparison, may seem too much compared to the national average. However, if they are consistent with yield data mentioned in the bibliography searched, 
where yields greater than $4,000 \mathrm{~kg} \mathrm{ha}^{-1}$ are reported when applied to irrigation (GOKSOY et al. 2004; KARAM et al. 2007; ANASTASI et al. 2010).

Table 4 shows the energy inputs per phase/stage in the production of oil and cake for Helio 358 variety. Table 5 shows these data for Aguará 04 variety.

TABLE 4. Energy inputs by phase and stage - Helio 358 variety.

\begin{tabular}{lccccc}
\hline \multicolumn{1}{c}{ Stages } & L0 & Lgricultural Phase $\left(\mathrm{MJ} \mathrm{ha}^{-1}\right)$ \\
Pre-sowing & 3787 & 3787 & L2 & L3 & L4 \\
Sowing & 1815 & 1815 & 1878 & 3787 & 3787 \\
Management & 3195 & 3195 & 3195 & 1815 & 1815 \\
Irrigation & - & 7998 & 9439 & 3195 & 3195 \\
Harvesting & 1529 & 1538 & 1543 & 10880 & 12327 \\
Subtotal & 10326 & 18333 & 19779 & 21247 & 22665 \\
\hline \multicolumn{7}{c}{ Extraction $\left(\mathrm{MJ} \mathrm{ha}^{-1}\right)$} \\
\hline Extraction & 789 & 849 & 879 & 1065 & 865 \\
\hline TOTAL & 11115 & 19182 & 20658 & 22312 & 23530 \\
\hline
\end{tabular}

TABLE 5. Energy inputs by phase and stage - Aguará 04 variety.

\begin{tabular}{lccccc}
\hline \multicolumn{1}{c}{ Stages } & Agricultural Phase $\left(\mathrm{MJ} \mathrm{ha}^{-1}\right)$ \\
Pre-sowing & 4688 & L1 & L2 & L3 & L4 \\
Sowing & 1815 & 4688 & 4688 & 4688 & 4688 \\
Management & 3195 & 3195 & 1815 & 1815 & 1815 \\
Irrigation & - & 3236 & 6638 & 3195 & 3195 \\
Harvesting & 1654 & 1682 & 1708 & 10037 & 13499 \\
Subtotal & 11352 & 14616 & 18044 & 21474 & 1768 \\
\hline \multicolumn{7}{c}{ Extraction $\left(\mathrm{MJ} \mathrm{ha}^{-1}\right)$} \\
\hline Extraction & 1614 & 1793 & 1981 & 217965 \\
\hline TOTAL & 12966 & 16409 & 20025 & 23644 \\
\hline
\end{tabular}

For both varieties, in the case of control (treatments L0), the stage which required more energy input was the pre-sowing, due to a large applying of the following inputs: limestone, diesel oil and herbicide. Comparing the data between the two Tables, it is apparent that, for Aguará 04 variety, the stage of pre-sowing consumed $23.8 \%$ more energy. This is explained by the large number of tillage operations, due to the use of conventional tillage technique.

In the case of irrigated treatments, the more representative stage of the power inputs of irrigation, also due to the issue of indirect energy of irrigation equipment. But, mainly, due to consumption of electricity for water pumping. For Helio 358 variety, it may be verified from the L1 treatment, because it has been assigned a greater value of water depth. For Aguará 04 variety, this can be seen from the treatment L2.

Figures 1 and 2 show the involvement of the input of energy intakes to produce sunflower oil and cake, for the Helio H358 Aguará 04 varieties, respectively.

It appears that the fossil energy represented by the sum of the energy of fertilizer, diesel oil and lubricants, has the largest weight in energy inputs in all treatments for both varieties. In most treatments, fertilizers showed the greatest weight. For treatments of the Aguará 04 variety, because it was used for conventional tillage, the weight of diesel oil is the most evident in power inputs.

In irrigated treatments, the electricity and equipment inputs have had great energy weight. For Helio 358 variety, with lower consumption of diesel oil in pre-treatment stage, the electricity input 
had greater weight than others from L2 treatment. For Aguará 04 variety, the same happened from L3 treatment. Both cases with a water depth around 300mm.

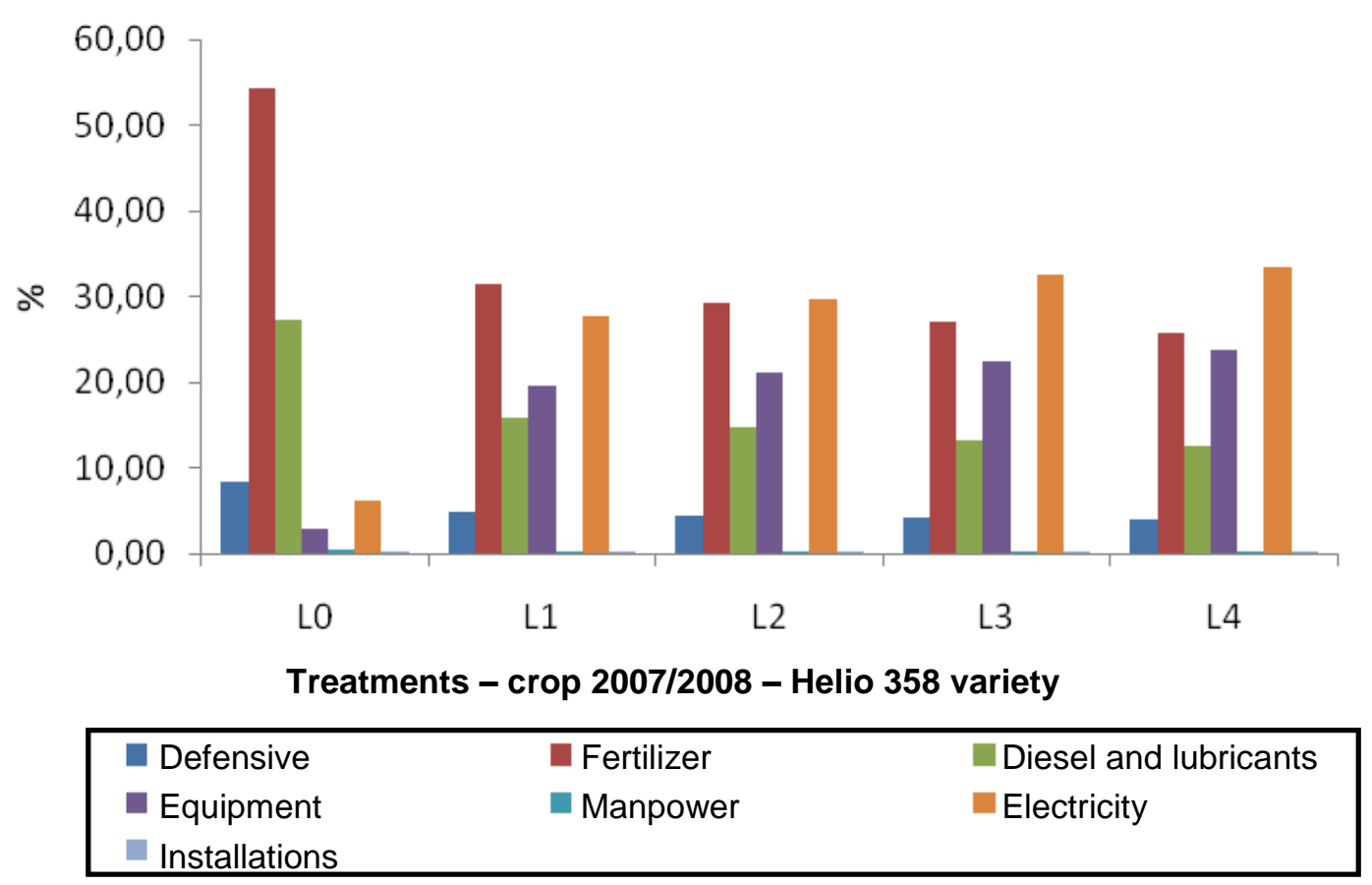

FIGURE 1. Participation of each input in the energy intakes for sunflower oil and cake yield (cold extraction) - H358 variety.

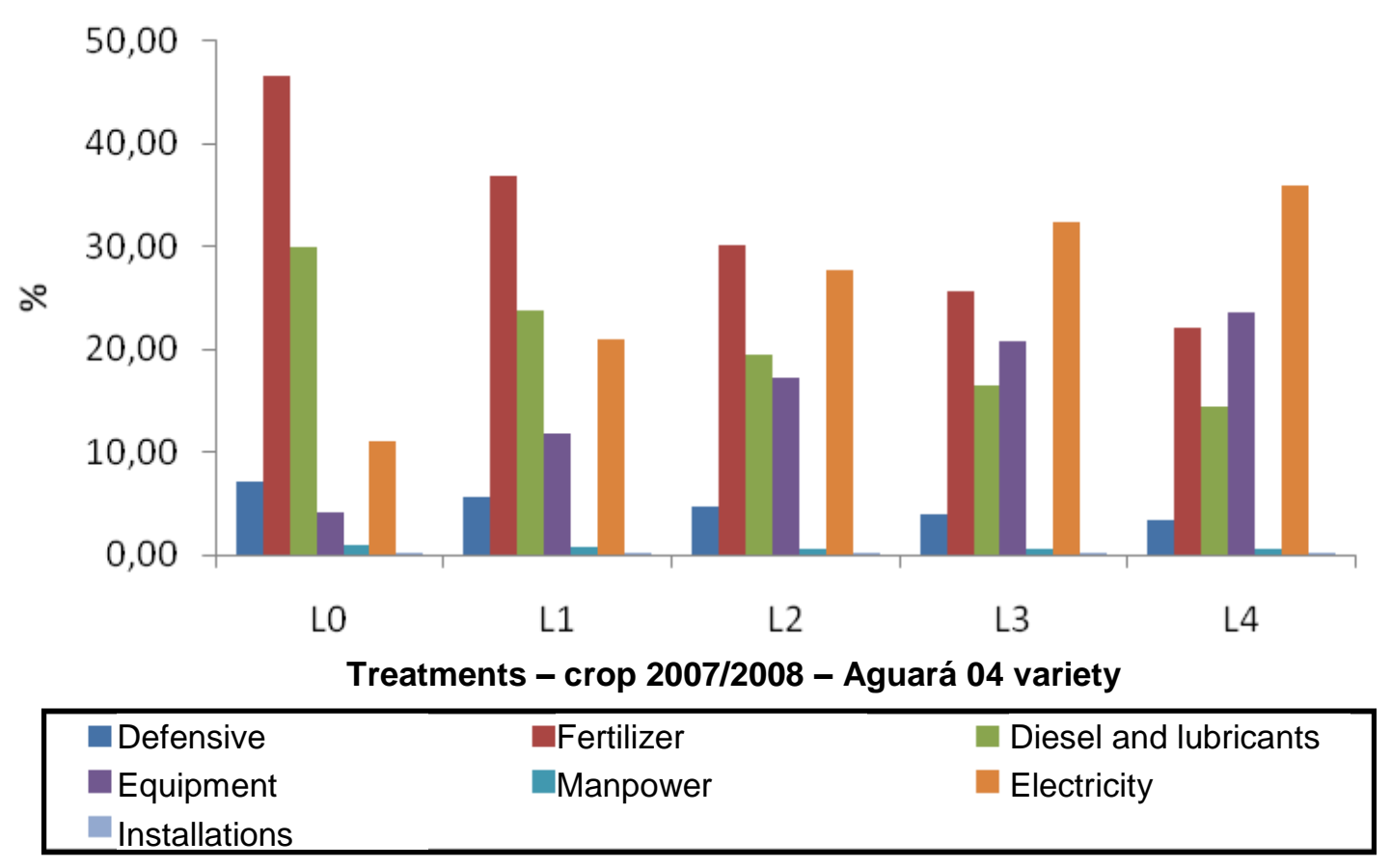

Figure 2. Participation of each input in the energy intakes for sunflower oil and cake yield (cold extraction) - Aguará 04 variety.

Tables 6 and 7 show the energy balance for the yield of sunflower oil and cake, respectively, for Helio 358 and Aguará 04 varieties. Due to the $80 \%$ efficiency of the cold extraction process, it was found that $20 \%$ of the oil exits mixed with the cake. 
TABLE 6. Energy balance in sunflower oil and cake yield (cold extraction) - agricultural phase and extraction $-\mathrm{H} 358$ variety.

\begin{tabular}{|c|c|c|c|c|c|}
\hline \multicolumn{6}{|c|}{ Yield $\left(\mathrm{kg} \mathrm{ha}^{-1}\right)$} \\
\hline Products & L0 & L1 & L2 & L3 & L4 \\
\hline Oil & 754 & 810 & 839 & 1017 & 826 \\
\hline Cake $(*)$ & 1517 & 1631 & 1689 & 2046 & 1662 \\
\hline Total & 2271 & 2441 & 2528 & 3063 & 2488 \\
\hline \multicolumn{6}{|c|}{ Energy outputs $\left(\mathrm{MJ} \mathrm{ha}^{-1}\right)$} \\
\hline Oil & 28410 & 30536 & 31625 & 38317 & 31124 \\
\hline Cake $(*)$ & 29355 & 31553 & 32677 & 39593 & 32160 \\
\hline Total & 57765 & 62089 & 64302 & 77910 & 63284 \\
\hline \multicolumn{6}{|c|}{ Energy inputs $\left(\mathrm{MJ} \mathrm{ha}^{-1}\right)$} \\
\hline Total & 11115 & 19182 & 20658 & 22312 & 23530 \\
\hline \multicolumn{6}{|c|}{ Energy balance (Outputs/Inputs) } \\
\hline Oil & 2.56 & 1.59 & 1.53 & 1.72 & 1.32 \\
\hline Cake $(*)$ & 2.64 & 1.64 & 1.58 & 1.77 & 1.37 \\
\hline Total & 5.20 & 3.24 & 3.11 & 3.49 & 2.69 \\
\hline
\end{tabular}

(*) With $20 \%$ of oil due to efficiency of cold extraction.

TABLE 7. Energy balance in sunflower oil and cake yield (cold extraction) - agricultural phase and extraction - Aguará 04 variety.

\begin{tabular}{lccccc}
\hline \multicolumn{7}{c}{ Yield $\left(\mathrm{kg} \mathrm{ha}^{-1}\right)$} \\
\hline Products & L0 & L1 & L2 & L3 & L4 \\
\hline Oil & 1608 & 1624 & 1713 & 2185 & 2344 \\
Cake $\left(^{*}\right)$ & 3034 & 3532 & 3984 & 4052 & 4435 \\
Total & 4642 & 5156 & 5647 & 6237 & 6779 \\
\hline \multicolumn{7}{c}{ Energy outputs $\left(\mathrm{MJ} \mathrm{ha}^{-1}\right)$} \\
\hline Oil & 60575 & 61190 & 64536 & 82348 & 88339 \\
Cake $\left(^{*}\right)$ & 59238 & 67659 & 75698 & 79299 & 86546 \\
Total & 119813 & 128849 & 140234 & 161647 & 174885 \\
\hline \multicolumn{7}{c}{ Energy inputs $\left(\mathrm{MJ} \mathrm{ha}^{-1}\right)$} \\
\hline Total & 12966 & 20025 \\
\hline Oil & 4.67 & Energy balance (Outputs/Inputs) \\
Cake $\left(^{*}\right)$ & 4.57 & 3.73 & 3.22 & 23644 \\
Total & 9.24 & 4.12 & 3.78 & 3.48 \\
\hline
\end{tabular}

(*) With $20 \%$ of oil due to efficiency of cold extraction.

In Table 6, comparing the control data with L4 treatment, which received the greater water depth $(400 \mathrm{~mm})$, it is apparent an increase of almost $10 \%$ in the total energy produced per hectare. Moreover, the increase in the amount of energy required, imprinted through the irrigation system, was approximately $112 \%$.

Making the same comparison for the data in Table 7, it is verified that, between control and the treatment that received the greater water depth, there was an increase greater than $45 \%$ of the total amount of energy extracted per hectare, while the increase in the amount of energy required was approximately $111 \%$.

By comparison, the Aguará 04 variety showed a better response to irrigation. However, in the final balance for both varieties, the energy gains achieved by irrigation do not surpass the increases of required energy, causing the balance to be negative. For the irrigation to be compensatory, varieties should have had presented very low yields without irrigation. However, this did not happen, because during the cycle, in the case of the two varieties, precipitation was around 450mm, a value set in the middle of the range required by the crop, which is 200 to $950 \mathrm{~mm}$ (SENTELHAS 
\& UNGARO, 1998; TYAGI et al., 2000; KARAM et al., 2007), which explains the satisfactory yield of control, above the national average.

If we consider the controls to a yield equal to the national average, of $1,500 \mathrm{~kg} \mathrm{ha}^{-1}$ (EMBRAPA, 2010), commonly obtained under second crop, the amount of energy extracted would be $37,500 \mathrm{MJ} \mathrm{ha}^{-1}$. Given the same amount of energy employed to control condition of the Helio 358 variety $\left(11,115 \mathrm{MJ} \mathrm{ha}^{-1}\right)$, the relation between extracted and used energy would be 3.37 . Then, there would have some gain only for the L3 treatment, not significant.

Considering this same situation in case of the Aguará 04 variety, the extracted energy/used energy relation employed to the control would be 2.89 . And, then, the irrigation would be compensatory in energy terms. However, it would still present decreases as the applied depth was increasing.

In terms of the extracted energy/used energy relation, the value found for the control of Helio 358 variety is consistent with values found in the literature. GAZZONI et al. (2010), also working with sunflower, found values of 1.61 for biodiesel and 2.69 for cake and biodiesel and biodiesel. JANULIS (2003) quoted by YANEZ et al. (2008) mentions a value of 2.54 for sunflower biodiesel.

Compared to the case of Brazilian ethanol, where the rate of extracted energy/fossil energy used is around 8.3 (BNDES \& CGEE, 2008), the relation obtained for the case of vegetable oils is still low, indicating a need to increase productivity with less energy use, for example, the use of more productive varieties. On the other hand, it is even better than the American ethanol, produced from maize, where this rate, also according to BNDES \& CGEE (2008), is less than 1.3.

\section{CONCLUSIONS}

The largest portion of the energy used in production was fossil, and fertilizers, mostly imported, accounted for a large portion.

Irrigation led to increase in yield and, consequently, in extracted energy in the form of oil and cake for both varieties in all treatments. However, yield gains in response to irrigation were more pronounced for Aguará 04 variety.

Under the conditions evaluated, for both varieties and in all treatments the increase in energy used with the use of irrigation was considerably higher than the energy gain, implying a negative response to irrigation.

\section{REFERENCES}

ANASTASI, U.; SANTONOCETO, C.; GIUFFRE, A. M.; SORTINO, O.; ABBATE, V. Yield performance and grain lipid composition of standard and oleic sunflower as affected by water supply. Field Crops Research, Amsterdam, v.119, p.145-153, 2010.

ANGONESE, A. R.; CAMPOS, A. T.; ZACARKIM, C. E.; MATSUO, M. S; CUNHA, F. Eficiência energética de sistema de produção de suínos com tratamento dos resíduos em biodigestor. Revista Brasileira de Engenharia Agrícola e Ambiental, Campinas Grande v.10, n.3, p.745-750, 2006. Campina Grande, PB.

ASSENHEIMER, A.; CAMPOS, A. T.; GONÇALVES JÚNIOR, A. F. C. Análise energética de sistemas de produção de soja convencional e orgânica. Ambiência. Revista do Setor de Ciências Agrárias e Ambientais, Guarapuava, v. 5 n. 3, set./dez. 2009.

BNDES; CGEE. Bioethanol production. In: Sugarcane-based bioethanol: energy for sustainable development. Rio de Janeiro, 2008. p. 64-96.

BRIGHENTI, A. M.; CASTRO, C.; MENEZES, C. C.; OLIVEIRA, F. A.; FERNANDES. P. B. Aplicação simultânea de dessecantes e boro no manejo de plantas daninhas e na nutrição mineral das culturas de soja e girassol. Planta Daninha, Viçosa, MG, v. 24, n. 4, p. 797-804, 2006. 
CASTRO, C.; MOREIRA, A.; OLIVEIRA, R. F.; DECHEN, A. R. Boro e estresse hídrico na produção do girassol. Ciência e Agrotecnologia, Lavras, v. 30, n. 2, p. 214-220, 2006.

CHECHETTO, R. G.; SIQUEIRA R.; GAMERO C. A. Balanço energético para a produção de biodiesel pela cultura da mamona (Ricinus communis L.). Revista Ciência Agronômica, v. 41, n. 4, p. 546-553, out-dez. 2010.

EMBRAPA - Empresa Brasileira de Pesquisa Agropecuária. Available in: www.cnpso.embrapa.br. Accessed in: 6 out. 2010.

EPE. Empresa Pesquisa Energética. Balanço Energético Nacional 2008: Ano base 2007. Rio de Janeiro: EPE, 2008. 244p.

GAZZONI , D. L.; FELICI, P. H. N.; CORONATO, R. M. e S. Balanço energético das culturas de soja e girassol para produção de biodiesel. Revista Biodiesel, Monte Alto, v. 2, n. 16, p. 26-28, maio, 2007.

GOKSOY, A. T.; DEMIR, A. O.; TURAN, Z. M.; DAGUSTU, N. Responses of sunflower to full and limited irrigation at different growth stages. Field Crops Research, Amsterdam, n.87, p.167178, 2004.

GOMES, E. P.; ÁVILA, M. R.; RICKLI, M. E.; PETRI, F.; FEDRI, G. Desenvolvimento e produtividade do girassol sob lâminas de irrigação em semeadura direta na região do Arenito Caiuá, Estado do Paraná. Irriga, Botucatu, v. 15, n. 4, p. 373-385, out./dez. 2010.

KAMPHORST, J. S. Quanto gasta seu trator. Revista Cultivar Máquinas, Pelotas, v.2, n. 24, p. 811, out. 2003.

KARAM, F.; LAHOUD, R.; MASAAD, R.; KABALAN, R.; BREIDI, J.; CHALITA, C.;

ROUPHAEL, Y. Evapotranspiration, seed yield and water use efficiency of drip irrigated sunflower under full and deficit irrigation conditions. Agricultural Water Management, Amsterdam, n.90, p.213-223, 2007.

MELLO, R.; NÖRNBERG, J. L.; RESTLE, J.; NEUMANN, M.; QUEIROZ, A. C.; COSTA, P. B.; MAGALHÃES, A. L. R.; DAVID, D. B. Características fenológicas, produtivas e qualitativas de híbridos de girassol em diferentes épocas de semeadura para produção de silagem. Revista Brasileira de Zootecnia, Viçosa, v. 35, n. 3, p. 672-682, 2006.

MELO, D.; PEREIRA, J. O.; SOUZA, E. G.; GABRIEL FILHO, A.; NÓBREGA, L. H. P.; PINHEIRO NETO, R. Energetic balance of soybean and corn production systems in a farm of the west of Paraná, Brazil. Acta Scientiarum Agronomy, Maringá, v. 29, n. 2, p. 173-178, 2007.

PACHECO, E. P. Seleção e custo operacional de máquinas agrícolas. Rio Branco: Embrapa Acre, 2000. 21p. (Documentos, 58).

SENTELHAS, P. C.; UNGARO, M. R. G. Índices bioclimáticos para a cultura de girassol. Scientia Agrícola, Piracicaba, v.55, n.1, p. 73-78, 1998.

SILVA, M. L. O.; FARIA, M. A.; MORAIS A. R.; ANDRADE, G. P.; LIMA, E. M. C. Crescimento e produtividade do girassol cultivado na entrassafra com diferentes lâminas de água. Revista Brasileira de Engenharia Agrícola e Ambiental, Campina Grande, v.11, n.5, p. 482-488, 2007.

TYAGI, N. K.; SHARMA, D. K.; LUTHRA, S. K. Determination of evapotranspiration and crop coeficients of rice and sunflower with lysimeter. Agricultural Water Management, Amsterdam, n.45, p.41-54, 2000.

YAÑES, E. E. A.; LORA, E. E. S.; COSTA, R. E da; LAMÔNICA, H. M.; FINGUERUT, J.; RAMIREZ, G. A. S.; NASCIMENTO, M. A. R. Produção de óleos vegetais e biodiesel: tecnologia e análise do ciclo de vida. In: Biomassa para Energia. Campinas: Editora Unicamp, 2008, p. 533571. 